\title{
EFEK KOMBINASI YAKULT DAN TAPIOKA PADA PROSES PEMBUATAN TEMPE TERHADAP KETAHANAN TEMPE DAN IMPLEMENTASINYA DALAM PEMBELAJARAN BIOLOGI BERBASIS SETS DIKELAS X SMA TUNAS PATRIA UNGARAN KAB SEMARANG
}

\author{
Sarini Rahayu ${ }^{1}$ \\ Universitas Negeri Semarang, Semarang, 50229 \\ Email Korespodensi: sarinirahayu@gmail.com
}

Diajukan: 1 January 2020; Diterima: 2 February 2020; Diterbitkan: 30 April 2020

\begin{abstract}
Abstrak: Penelitian ini bertujuan untuk mengkaji tentang 1) Bagaimana daya simpan tempe dengan pemberian yakult dan tapioka .2) Bagaimana jamur kapang terdapat dalam tempe. 3) Untuk mengetahui kualitas hasil belajar siswa tentang materi fungi dengan menggunakan E LKS berbasis SETS pada materi fungi di kelas X SMA TUNAS PATRIA UNGARAN. Jenis penelitian ini adalah eksperimen semu dengan Berdasarkan hasil penelitian diperoleh lama simpan tempe yang paling bagus pada penemabahan yakult $20 \%$ dan tapioka 0,8 \% P2 B2 dengan lama simpan umur tempe pada hari ke enam. Kesukaan masyrakat terhadap rasa atau aroma khas tempe dapat diuji dengan organoleptik selain aroma dapat diketahui kekompakan dan warna. Aroma khas tempe dapat diketahui dengan nilai tertinggi pada penambahan yakult dan tapioka P1 B2 dan P2 B2 sebanyak 90 dan 91 total keseluruhan dengan rata rata sangat suka. kesukaan masyarakat pada aroma tempe kedelai pada K1B1, K1B2, kedelai dan ragi, P1 B1, P1B2 kedelai ragi, dan yakul ,P2 B1, P2B2 Kedelai ,ragi dan tapioka P3 B1, P3B2 kedelai, ragi yakul dan tapioka dari hari perta sampai hari ke 4 dan hari kelima dan selanjutnya sudah tercium aroma amoniak. Kekompakkan pada tempe dapat dilihat K1B1, K1B2, kedelai dan ragi, P1 B1, P1B2 kedelai ragi, dan yakul ,P2 B1, P2B2 Kedelai ,ragi dan tapioka P3 B1, P3B2 kedelai, ragi yakul dan tapioka dari hari pertama sampai hari ke 7 dan hari ketujuh dan selanjutnya sudah tidak terlihat kompak meselium tidak menyebar dipermukaan tempe warna pada tempe dapat dilihat K1B1, K1B2, kedelai dan ragi, P1 B1, P1B2 kedelai ragi, dan yakul ,P2 B1, P2B2 Kedelai ,ragi dan tapioka P3 B1, P3B2 kedelai, ragi yakul dan tapioka berwarna putih pada hari 2 sampai hari ke 5 dan hari ke 6 selanjutnya berwarna coklat pada Implikasi pembelajaran dengan penerapan pendekatan Sains Teknologi Lingkungan dan Masyarakat (Salingtemas) pada pokok bahasan fungi di kelas X IPA SMA TUNAS PATRIA UNGARAN Kabupaten Semarang pada pertemuan II aspek afektif adalah $82,35 \%$, dengan ketuntasan klasikal adalah 88\%, psikomotorik adalah 80,17\% dengan ketuntasan klasikal 94\%,aspek kognitif adalah 78,72\%, dengan ketuntasan klasikal 88\%.
\end{abstract}

Kata Kunci: Tempe, Yakul, Tapioka, SETS, Hasil Belajar.

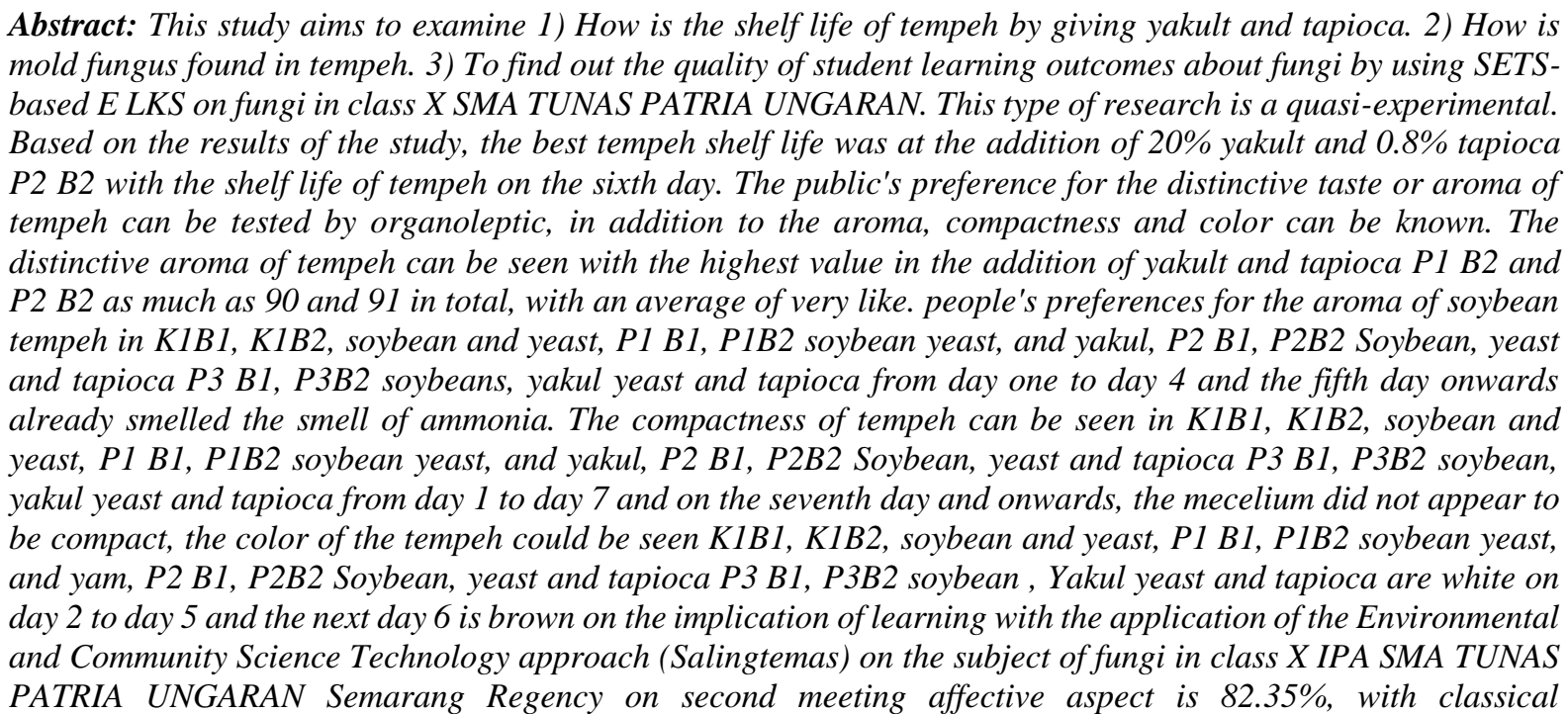


completeness is $88 \%$, psychomotor is $80.17 \%$ with classical completeness $94 \%$, cognitive aspect is $78.72 \%$, with classical completeness $88 \%$.

Keywords: Tempe, Yakul, Tapioca, SETS, Learning Outcomes

\section{Pendahuluan}

Beberapa peran mikroorganisme yang menguntungkan dalam bidang pangan seperti tempe. Tempe adalah makanan khas indonesia yang merupakan produk fermentasi yang berbahan utama kedelai serta memilki nilai gizi yang baik. Fermentasi pada tempe terjadi melalui aktivitas kapang Rhizopus oryzae.(Aptesia et al, 2013)

Kedelai sebagai bahan pembuat tempe memiliki kandungan gizi yang baik seperti tinggi protein nabati, kaya akan asam amino serta serat yang baik untuk tubuh. Tempe berasal dari jawa, dalam manuskrip serat centhini ditemukan bahwa masyarakat jawa telah mengenal "Tempe" pada abad ke 16 (Badan Standarisasi Nasional 2012).

Tempe sebagai makanan khas indonesia hampir selalu ada disetiap lapisan masyarakat, dan diproduksi disetiap daerah. Permasalahan bagi pengrajin atau pengusaha dan konsumen dari tempe adalah daya simpan tempe yang cukup cepat, menyebabkan pengusahan harus dapat memasarkan tempe secara cepat agar tidak mengalami kerugian. Salah satu solusi yang ditawarkan adalah penambahan tepung tapioka dan bakteri Lactobacillus casei.

E.LKS adalah suatu alat kegiatan dalam proses pembelajaran yang tersusun secara terprogram, di software di dalam E.LKS memuat materi- materi yang akan di ajarkan oleh guru. Pada pembelajaran Biologi dengan metode diskusi menggunakan E.LKS. Yang mana E.LKS sudah disusun secara terprogram, sehingga siswa dapat mengikuti pelajaran yang dibuat oleh guru sesuai dengan kompetensi. Sebelum siswa mengerjakan E.LKS tersebut terlebih dahulu satu persatu soal - soal atau permasalahan itu didiskusikan.di dalam E.LKS terdiri dari:(1) Judul, (2) tujuan, (3)standar kompetensi, (4) informasi, (5) pertanyaan.

Menurut Rochman (2009:1) secara umum E.LKS dapat dibedakan menjadi tiga jenis, yaitu lembaran observasi lapangan, lembaran eksperimen siswa dan lembaran pengkajian yang langsung dihubungkan dengan buku teks atau disebut juga DART (Direct Activity to Relate to The Text Book). Jenis yang ketiga ini yang paling sering dipakai oleh semua mata pelajaran. Sedangkan E.LKS jenis observasi dan eksperimen siswa umumnya banyak dipakai untuk keperluan mata pelajaran MIPA.

Pendekatan sains teknologi lingkungan dan masyarakat salingtemas atau Pendekatan Science, Environment, Technology, Society (SETS) adalah sutu pendekatan yang di lakukan oleh guru dalam prroses belajar mengajar di mana siswa dapat menggunakan teknologi yang sederhana yang berkaitan dengan materi pelajaran dan di harapkan nanti siswa mempunyai skill dan dapat diaplikasikan di dalam masyarakat. pengetahuan yang berupa fakta-fakta, konsep-konsep atau prinsip-prinsip saja, tetapi juga merupakan suatu proses penemuan yang sesuai dengan era abad ke 21 . Biologi sebagai salah satu bidang IPA menyediakan berbagai pengalaman belajar untuk memahami konsep dan proses sains.

Keterampilan proses ini meliputi keterampilan mengamati, mengajukan hipotesis, menggunakan alat dan bahan secara baik dan benar dengan selalu mempertimbangkan keamanan dan keselamatan kerja, mengajukan pertanyaan, menggolongkan dan menafsirkandata,serta mengkomunikasikanhasil temuan secara lisan atau tertulis, menggali dan memilah informasi faktual yang relevan untuk menguji gagasangagasan atau memecahkan masalah sehari-hari. Hasil penelitian eksperimen dilaboratorium akan diimplementasi di sekolah dengan menggunakan pendekatan saling-temas. Pendekatan sains teknologi masyarakat merupakan pendekatan pembelajaran yang pada dasarnya membahas penerapan sains dan teknologi dalam konteks kehidupan manusia sehari-hari. Oleh karena itu pendekatan sains teknologi masyarakat disebut sebagai pendekatan terpadu antara sains dan isu-isu teknologi yang ada dalam masyarakat. Dengan pendekatan ini siswa dikondisikan diharapkan mampu menerapkan prinsip-prinsip sains untuk menghasilkan karya teknologi sederhana atau solusi pemikiran untuk mengatur dampak negatif yang mungkin timbul akibat munculnya produk teknologi. Asyari, (2006) menyatakan 
bahwa "pendekatan SETS efektif untuk meningkatkan penguasaan konsep dalam diri siswa dan dalam penerapannya di lapangan diharapkan dapat menunjukan kemampuan menerapkan konsep sains dalam kehidupan sehari-hari" permasalahan yang diteliti dalam peneliti yaitu 1) Bagaimana daya simpan tempe dengan pemberian yakult dan tapioka .2) Bagaimana jamur kapang terdapat dalam tempe. 3) Untuk mengetahui kualitas hasil belajar siswa tentang materi fungi dengan menggunakan E.LKS berbasis SETS pada materi fungi di kelas X SMA TUNAS PATRIA UNGARAN.

\section{Metode Penelitian}

Penelitian ini dilaksanakan pada tanggal 16 September 2019, yang bertempat di SMA TUNAS PATRIA UNGARAN Kelas X . Alat yang digunakan untuk pembuatan tempe : tampah besar, sarung tangan plastic, panci, saringan, timbangan, keranjang, pengaduk kayu, dandang, kompor, termometer dan plastik pengemas. Bahan yang digunakan antara lain : Kacang kedelai putih, Ragi tempe, Air, Tepung tapioca, Penelitian ini dilakukan untuk mengetahui pengaruh penambahan bakteri asam laktat dan penambahan media berupa tepung tapioka yang memiliki lama simpan maksimal dan masih memiliki sifat organoleptik sesuai SNI. Selanjutnya perlakuan terbaik akan diuji organoleptic terhadap bau, kekompakan dan warna dari tempe kedelai menggunakan panca indera secara langsung. Data yang didapat dibahas menggunakan analisis dekskriptif Kualitatif.

\section{Penelitian Pendidikan}

Langkah pertama yang dilakukan dalam menganalisis data adalah dengan cara pengumpulan data dari lapangan terlebih dahulu, kemudian data instumen yang berupa Lembar Observasi (LO). Data observasi yang diperoleh nantinya di gunakan untuk merefleksi siklus yang telah dilakukan dan diolah secara deskriptif. Dalam penelitian ini, digunakan data secara deskriptif kualitatif. dengan persentase (Arikunto, 1996 dalam Rahmi, 2010). Hasil tes diolah dengan persen ketercapaian atau daya serap. Siswa dikatakan tuntas belajar secara individu bila mendapat nilai $\geq 70$, sedangkan secara klasikal proses belajar mengajar dikatakan tuntas
Instrumen penelitian adalah alat yang dibutuhkan atau dipakai untuk pengumpulan data. sesuai dengan penelitian yang digunakan, maka dalam penelitian ini digunakan instrumen berupa hasil tes siswa, LKS, pedoman observasi, serta angket/kuesioner.Hasil tes siswa dengan hasil la siswa memperoleh nilai $\geq$ 70 sebanyak 70\% (Depdikbud dalam Rahmi, 2010).

\section{Instrumen Penelitian}

Tes tulis adalah tes dimana soal dan jawaban yang diberikan kepada siswa dalam bentuk bahan tulisan. Tes tulis/tes hasil belajar digunakan untuk mengukur pengetahuan atau penguasaan objek ukur terhadap seperangkat konten atau materi tertentu. tes tertulis juga digunakan untuk mengukur dan menilai hasil belajar siswa, terutama hasil belajar kognitif berkenaan dengan penguasaan bahan pengajaran dengan tujuan pendidikan dan pengajaran. E LKS merupakan salah satu sarana untuk membantu dan mempermudah dalam kegiatan belajar mengajar sehingga akan terbentuk interaksi yang efektif antara siswa dengan guru, sehingga dapat meningkatkan aktifitas siswa dalam peningkatan prestasi belajar. Tahap pelaksanaan tindakan Pelaksanaan tindakan ini direncanakan dengan langkah -langkah sebagai berikut: 1) invite Dalam proses pembelajaran melibatkan dan mengajak siswa. spontan guru Mengidentifikasi situasi dimana siswa berbeda persepsi. Guru mengemukakan isu-isu atau masalah aktual yang ada dimasyarakat dikaitkan dengan konsep-konsep yang akan dibahas, tahap ini disebut apersepsi. 2) explore. Siswa dilibatkan untuk mengumpulkan data melalui eksperimen, dan diskusi. 3) purpose explanation and solution. Siswa mengajukan penjelasan berdasarkan data yang diperoleh. Siswa mengalami perubahan konsepsi. Konsep yang sudah dipahami peserta didik dapat digunakan untuk menyelesaikan masalah atau menganalisis isu-isu atau masalah yang sudah dilontarkan pada awal pembelajaran, tahap ini dianggap sebagai aplikasi konsep. 4)Take Action.siswa membentuk konsep baru, mengambil keputusan dan tindakan. Pedoman observasi 


\section{Hasil penelitian dan Pembahasan}

\section{Daya simpan}

Tujuan penelitian utama adalah menentukan daya tahan tempe kedelai dengan penambahan L.casei serta tapioka setelah proses fermentasi 48 jam, sampai ditemukan lama simpan yang menunjukkan terjadinya perubahan sifat organoleptik yang tidak memenuhi SNI. Adapun parameter yang diamati adalah warna, bau dan kekompakan menggunakan panca indera (Gambar 1).

Berdasarkan hasil pengamatan, tempe pada hari pertama memiliki kondisi yang sama seperti dengan tempe normal tanpa penambahan tapioka dan L.casei dengan ciriciri memiliki tekstur kompak dan padat, bewarna putih kekuningan, aroma khas tempe dan belum timbul bau amonia. Lama peyimpanan maksimal tempe dengan penambahan tapioka $0,8 \%$ dan yakult $20 \%$ adalah 7 hari. Semakin panjang lama peyimpanan, maka kondisi fisik tempe semakin menurun. Seperti yang sudah dilakukan eksperimen pembuatan tempe oleh Aptesia, et al. 2013 menyatakan bahwa tempe dengan konsentrasi tapioka 0,8\% dan L.casei $20 \%$ memiliki daya tahan peyimpanan yang terbaik yaitu bertahan sampai dengan 7 hari. Pada pengamatan dari tempe dengan 3 perlakuan yang mana kondisi fisik tempe kedelai yang meliputi warna, bau, rasa, tekstur, dan penerimaan keseluruhan normal masih layak untukdikonsumsi.

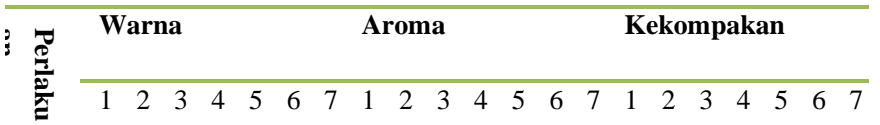

$\begin{array}{lllllllllllllllllllllll}\mathrm{K} & \mathrm{B} & 7 & 7 & 7 & 4 & 3 & 2 & 1 & 7 & 7 & 7 & 3 & 2 & 1 & 0 & 7 & 7 & 7 & 5 & 4 & 4 & 4\end{array}$ 1

$\begin{array}{llllllllllllllllllllll}\text { B } & 7 & 7 & 7 & 4 & 3 & 2 & 1 & 7 & 7 & 7 & 3 & 2 & 1 & 0 & 7 & 7 & 7 & 5 & 4 & 4 & 4\end{array}$ 2

$\begin{array}{lllllllllllllllllllllll}\mathrm{P} & \mathrm{B} & 7 & 7 & 7 & 6 & 5 & 4 & 3 & 7 & 7 & 7 & 6 & 5 & 4 & 3 & 7 & 7 & 7 & 7 & 6 & 6 & 6\end{array}$ $1 \quad 1$

$\begin{array}{llllllllllllllllllllll}\text { B } & 7 & 7 & 7 & 6 & 5 & 4 & 3 & 7 & 7 & 7 & 6 & 5 & 4 & 3 & 7 & 7 & 7 & 7 & 6 & 6 & 6\end{array}$

$\begin{array}{lllllllllllllllllllllll}\mathrm{P} & \mathrm{B} & 7 & 7 & 7 & 7 & 7 & 6 & 5 & 7 & 7 & 7 & 7 & 6 & 5 & 4 & 7 & 7 & 7 & 7 & 6 & 6 & 6\end{array}$ $2 \quad 1$

$\begin{array}{llllllllllllllllllllll}\text { B } & 7 & 7 & 7 & 7 & 7 & 6 & 4 & 7 & 7 & 7 & 7 & 6 & 5 & 4 & 7 & 7 & 7 & 7 & 6 & 6 & 6\end{array}$

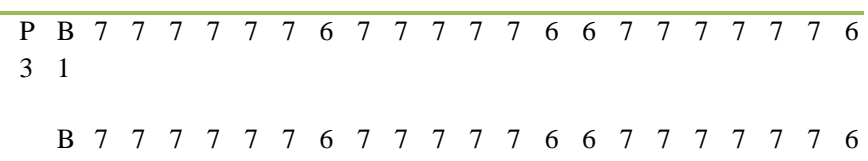

Gambar :Tabel 1 Pengamatan Fisik Tempe

\section{Uji Organoleptik}

Secara keseluruhan pengamatan fisik, pengamatan daya tahan tmpe dan kuesioner, tempe secara warna tidak berbeda jauh dengan warna tempe umunya yaitu warna putih miselium namun ada sedikit warna kuning dari penambahan yakult Menurut Winarno (2002) penerimaan warna suatu bahan makanan tergantung dari faktor alam, geografis dan aspek sosial masyarakat penerima, dan warna yang paling tahan selama tujuh hari adalah pada perlakuan ketiga pada batch 1 yang merupakan kedelai + Ragi + Yakult + Tepung.

Pengamatan tempe secara aroma, aroma khas tempe menjadi indikator tempe yang baik, dan aroma amoniak menjadi indikator tempe yang buruk. Selama pengamatan tujuh hari aroma tempe yang paling setabil dan tahan adalah pada perlakuan ke tiga pada batch 2 yaitu merupakan kedelai + Ragi + Yakult + Tepung.

Pengamatan tempe secara kekompakan, kekompakan tempe bisa dilihat dari miselium yang masih menyelimuti kedelai menujukan sebagai tempe dengan kekompakan baik. Tempe dengan hasil pengamatan kekompakan terbaik selama tujuah hari adalah pada perlakuan ke dua pada batch 2 yaitu merupakan kedelai + Ragi + Tepung.Hasil pengamatan fisik dapat disimpulkan bahwa yakult yang ditambahkan berfungsi untuk memperlambat proses pembusukan. Disamping itu, tapioka merupakan media tumbuh yang baik bagi jamur (karena mengandung protein, karbohidrat sebagai nutrisi) sehingga penambahan yakult dan tepung tapioca sangat berpengaruh positif terhadap keadaan fisik tempe.

Berdasarkan hasil pengamatan kesukaan tempe, melalui angket atau kuesioner kesukaan tempe secara keselurahan rata-rata hasil dari 30 sempel siswa yang mengamati secara langsung, tempe dengan respon positif dengan rata-rata nilai terbaik tentang kesukaan adalah pada kontrol batch 1 dan 2, perlakuan 
pertama batch 1, dan perlakuan dua pada batch 2. Hasil ini menunjukan bahwa Kontrol (Kedelai+ragi); perlakuan pertama (Kedelai+ragi+Yakult); perlakuan kedua (Kedelai+Ragi+Tepung) sehingga disimpulkan secara kesukaan penambahan yakult dan tepung tapioca disukai oleh siswa karena merubah rasa menjadi asam. 90 dan 91 .

C. Uji implementasi efek kombinasi yakult dan tapioka pada proses pembuatan tempe terhadap ketahanan tempe pada pembelajaran Biologi

Langkah - langkah pembelajarannya adalah: (1) Menyiapkan perangkat pembelajara Perangkat pembelajaran tersebut berupa: a. Berupa Rancangan Pelaksanaan Pembelajaran (RPP) meliputi: (1) tujuan pembelajaran, (2) kegiatan pembelajaran, (3) materi pembelajaran, dan (4) Evaluasi. b. Menyusun indikator,

dan kriteria pencapaian hasil belajar siswa. c. Menyusun alat perekam data berupa: pedoman observasi, yaitu lembar observasi aktivitas guru dan siswa. Deskripsi hasil observasi aktivitas guru dengan menggunakan pendekatan salingtemas oleh dua orang pengamat pada aktivitas guru dalam kategori baik. Dari hasil observasi ada beberapa aspek dalam kategori baik. Aspek- aspek dalam kategori cukup adalah menkomunikasi tujuan pembelajaran dan memotivasi belajar siswa, sedangkan menyampaikan masalah yang aktual baik, dan mendefinisikan tugas belajar siswa dengan masalah yang akan dikerjakan baik. Berdasarkan hasil analisis data aktivitas guru yang dilakukan oleh pengamat 1 dan 2 diperolah nilai rata sebesar 28,5 yang termasuk dalam kategori baik dimana dari pengamatan satu 29 dan pengamatan dua 28.

Tabel 2 Hasil analisis data observasi akitivitas guru

\begin{tabular}{cc}
\hline Pengamat & Skor \\
\hline $\mathbf{1}$ & 29 \\
$\mathbf{2}$ & 28 \\
Jumlah & 57 \\
Rata -rata & 28,5 \\
Kategori penilai & Baik \\
\hline
\end{tabular}

Pada kompetensi dasar 4.6 Menyajikan data hasil pengamatan ciri-ciri dan peran jamur dalam kehidupan dan lingkungan dalam bentuk laporan tertulis proses pembelajaran menggunakan pendekatan SETS , Berdasarkan hasil analisis data nilai psikomotorik siswa yang dilakukan oleh peneliti diperoleh nilai rata- rata sebesar 80,17 dan ketuntasan klasikal 94\% Hal ini terlihat sudah optimalnya proses pembelajaran pada tahap: Merangkai alat percobaan Siswa merangksi alat percobaan dengan benar sesuai dengan petunjuk yang ada di dalam E.LKS - Menggunakan alat dan bahan Siswa belum menggunakan alat dan bahan dalam percobaan dengan tepat. - Pengambilan data Siswa ,mencatat data dengan benar. Deskripsi nilai akhir siswa (kognitif) Pada proses pembelajaran menggunakan pendekatan saling temas pada kompetensi 3.6 Menerapkan prinsip klasifikasi untuk menggolongkan jamur berdasarkan ciri-ciri dan cara reproduksinya melalui pengamatan secara teliti dan sistematis dengan pendekatan SETS, tes siklus II dilaksanakan pada akhir pembelajaran. Berdasarkan hasil tes kognitif , nilai tersebut di analisis dengan mencari rata- rata kelas 78,72 dan ketuntasan klasikalnya $88 \%$ sedangkan pada aspek afektifnya adalah 82,35 dengan ketuntasan klasikal adalah $88 \%$ Hasil tes siswa kelas X SMA Tunas Patria Ungaran Karena kriteria ketuntasan belajar minimum siswa yang di berlakukan di SMA Tunas Patria Ungaran adalah $70 \%$ siswa dengan hasil belajar nilai 7,0 untuk mata pelajaran Biologi. ketuntasan kriteria yang di berlakukan di SMA Tunas Patria Ungaran yang ketuntasan klasikalnya adalah $70 \%$ dengan kriteria ketuntasan minimum 70 untuk mata pelajaran biologi. Berdasarkan dari data yang sudah di analisis, bahwa penerapan E.LKS berbasis SETS mengalami hasil belajar yang opimal baikituyangterjadipadagurumaupunpadasiswas udahdikategorikanbaik.

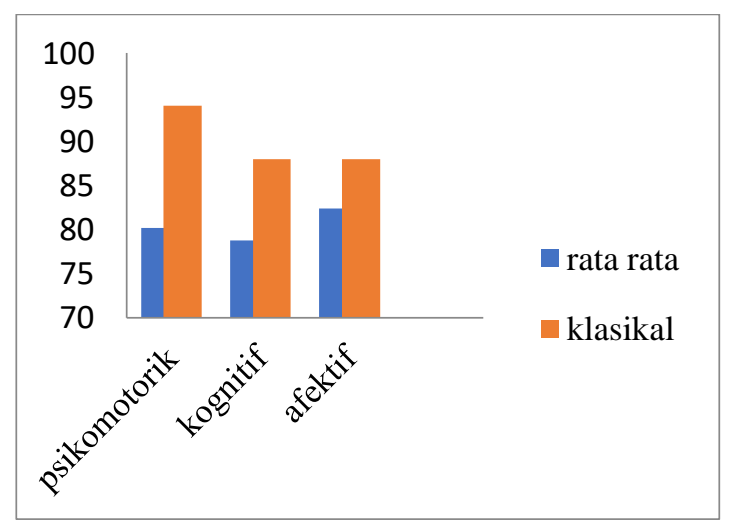

Gambar : Diagram Hasil Nilai Siswa Kelas X SMA TUNAS PATRIA UNGARAN 


\section{Simpulan}

Daya simpan terbaik ada pada tempe dengan tapioka $0,8 \%$ dan yakult $20 \%$ dengan lama penyimpanan maksimal pada produk tempe 7 hari. Pada kondisi ini fisik tekstur kompak padat, tempe bewarna putih kekuningan, belum timbul bau amonia. Penambahan tapioka memberikan pengaruh yang nyata terhadap kekompakan, aroma, warna, dan rasa keseluruhan pada tempe kedelai.dan berdasarkan analisis data nilai psikomotorik siswa rerata80,17 ketuntasan klasikal 94\%, nilai kognitif rerata 78,72 ketuntasan klasikal $88 \%$ dan aspek afektif rerata 82,35 ketuntasan klasikalnya $88 \%$.

\section{Saran Dan Rekomendasi}

Saran kepada guru MIPA bahwa dengan pembelajaran berbasis SETS dapat diimpilkasikan didalam perangkat pembelajarannya K13, sehingga meningkatkan motivasi dan hasil belajar siswa dan siswa dapat mengenal lebih jauh tentang isu -isu dalam pembelajaran MIPA khususnya Biologi , serta untuk para usaha dibidang industri tempe dengan adanya efek anatara pemberian yakult dan tapioka dapat memperoleh daya tahan tempe 7 hari sehingga dengan adanya inovasi terkini dapat membantu para industri tempe untuk mengembangnkan produksinya dan dapat meningkatkan taraf ekonomi dengan daya tahan tempe cukup lama

\section{Daftar Pustaka}

Afzal, A., Mahmood, M.S., Hussain, I., Akhtar, M,. 2011. Adulteration and Microbiological
Quality of Milk. A Review. Pakistan J. Nutrition 10(12): 1195-1202.

Afriani., 2009. Pengaruh Penggunaan Starter Bakteri Asam Laktat Lactobacillus plantarum dan Lactobacillus fermentum terhadap Total Bakteri Asam Laktat, Kadar Asam dan Nilai pH Dadih Susu Sapi. J. Ilmiah Ilmu-Ilmu Peternakan 8(6): 279-285.

Aptesia, Lidia Tri., Suharyono., Harul Al Rasyid. 2013. Pemanfaatan Lactobacillus casei dan tapioca dalam upaya menghambat kerusakan tempe kedelai. Universitas Lampung

Asaminew, T.,Eyassu, S., 2011. Microbial Quality of Raw Cow's Milk Collected from Farmers and Dairy Cooperatives in Bahir Dar Zuria and Mecha District, Ethiopia. Agric. Biol. J. N. Am.2: 29-33.

Casarotti, S.N., Monteiro, D.A., Moretti, M.M.S., Penna, A.L.B., 2014. Influence of the combination of probiotic cultures during fermentation and storage of fermented milk. Food Res Intern, 59:67-

Guimaraes, P.M.R., Teixeira, J.A, Domingues, L., 2010. Fermentation of lactose to bio-ethanol by yeast as part of integrated solution for the valorization of cheese whey. Biotechnol Adm 28: 375-384.

Kemala ,sari .1990. Upaya Memperpanjang Umur Simpan Tempe Dengan Metode Pengeringan Dan Sterelisasi Departemen Teknologi Pangan Dan Gizi Fakultas Teknologi Pertanian Institut Pertanian Bogor. Bogor . $5 \mathrm{hlm}$

Siswono. 2003.. Tiada Hari Tanpa Tempe http/.ww.gizi.net $1 \mathrm{hlm}$ Diakses tanggal2 maret 2012 .hlm 2.

Winarno, F.G.1992. Kimia Pangan dan Gizi. Gramedia. Jakarta. 43 hlm. 